\title{
The practice of settling and enacting strategic guidelines for climate adaptation in spatial planning: lessons from ten Swedish municipalities
}

Sofie Storbjörk and Ylva Uggla

\section{Linköping University Post Print}

\section{Tweet}

N.B.: When citing this work, cite the original article.

The original publication is available at www.springerlink.com:

Sofie Storbjörk and Ylva Uggla, The practice of settling and enacting strategic guidelines for climate adaptation in spatial planning: lessons from ten Swedish municipalities, 2015, Regional Environmental Change, (15), 6, 1133-1143.

http://dx.doi.org/10.1007/s10113-014-0690-0

Copyright: Springer Verlag (Germany)

http://www.springerlink.com/?MUD=MP

Postprint available at: Linköping University Electronic Press

http://urn.kb.se/resolve?urn=urn:nbn:se:liu:diva-111231 


\section{The practice of settling and enacting strategic guidelines for climate adaptation in spatial planning. Lessons from ten Swedish municipalities}

Sofie Storbjörk, corresponding author, Department of Water and Environmental Studies (WES) and Centre for Climate Science and Policy Research (CSPR), Linköping University, 58183 Linköping, Sweden. Phone: +46 13 282952. E-mail: sofie.storbjork@liu.se

Ylva Uggla, Centre for Urban and Regional Studies (CUReS), Örebro University, 70182 Örebro, Sweden. Phone: +46 19 303271. E-mail: ylva.uggla@oru.se

Accepted for publication in Regional Environmental Change. DOI: 10.1007/s10113-0140690-0

\section{Abstract}

Spatial planning is increasingly expected to address climate change adaptation. In a Swedish context this has meant a predominant focus on risks of flooding, erosion and sea-level rise. Gradually, regulatory mechanisms and concrete strategies are evolving to support practical mainstreaming. The aim of this paper is to analyze how frontline planners approach climate change adaptation in an urban context, emphasizing the process of settling and enacting strategic guidelines in spatial planning. The study suggests that municipalities are being preactive i.e. preparing to act by settling guidelines rather than proactively implementing change when planning for new settlements. Further the process of accommodating climate risks involves problems. Settling strategic guidelines and determining appropriate levels for what to adapt to are but the start of approaching climate change. Guidelines represent more of an endeavor than settling absolute limits and actually applying the guidelines involves challenges of accessibility and aesthetics where the new waterfront limits meets older city structures. Further, guidelines are seen as negotiable since an overarching principle is to maintain flexibility in planning to allow for continued waterfront planning. Pursuing this path is motivated by current demand and previous urban settlement patterns. Also, as future protective measures are needed to secure existing urban areas at risk of flooding and erosion planners see no use in preventing further waterfront development. Although settling guidelines are important in preparing to act, their practical effectiveness all fall back to how they are actually implemented in daily planning. This leads us to problematize the role of strategic guidelines to secure a climate-proof spatial planning.

Key words: climate adaptation, spatial planning, implementation, frontline practitioners, strategic guidelines, negotiating order

Word count: 8570, including title page, table and references. 


\section{Introduction}

Spatial planning is seen as one key arena where mainstreaming of climate adaptation, integrating climate change considerations in the operations of existing policy- and decisionmaking areas (Adger et al. 2007; Urwin and Jordan 2008; Adger and Barnett 2009), is expected. Spatial planning as an adaptation policy response reinforces the local perspective and means addressing the consequences of climate change in the ongoing regulation of landuse change and the integration and balancing of societal goals in designing and developing urban and rural areas (Campbell 2006; Wilson 2006; Biesbroek et al. 2009; Wilson and Piper 2009; Davoudi et al. 2009; Amundsen et al. 2010; Uittenbroek et al. 2012). In this respect planning can either increase the local capacity to deal with climate risks or "lock future generations into development pathways that increase vulnerability" (Rayner 2012, 41; Pielke et al. 2007). Studies of initial climate adaptation in Europe, North America and Australia document that municipalities tended to adopt wait-and-see approaches with reactive or eventdriven adaptations relying upon technical measures and mostly focusing on climate variability and current weather extremes rather than climate change (Næss et al. 2005; Storbjörk 2007; Uggla 2009; Glaas et al. 2010; Burch 2010; Amundsen et al. 2010; Preston et al. 2011; Runhaar et al. 2012; Dannevig et al. 2012; Nilsson et al. 2012). Further, studies in the Global North and South suggest that practical climate proofing include problematic positions in mediating conflicting values, interests and positions resulting in limited, fragmented and piecemeal integration where local authorities call for guidelines and recommendations for how to act (Wilson 2006; Blanco and Alberti 2009; Vasey Ellis 2009; Glaas et al. 2010; Amundsen et al. 2010; Dovers and Hezri 2010; Storbjörk and Hedrén 2011; Anguelovsky and Carmin 2011; Measham et al. 2011; Romero-Lankao 2012; Hurlimann and March 2012).

Gradually, different strategies for the climate adaptation of spatial planning have evolved. In countries like the Netherlands, the UK, Germany and Sweden, the spatial planning element of climate adaptation policy has been executed by different regulatory mechanisms (Swart et al. 2009; Huitema et al. 2012). In Sweden the main formal policy instrument has been legislative changes in the Planning and Building Act (PBA), intended to make sure that the consequences of climate change are dealt with in municipal comprehensive plans, local development plans and granting of building-permits (PBL 2010:900; Nilsson et al. 2012). In practice this has meant two things, a predominant focus on risks of flooding, erosion and sea-level rise and a focus on identifying and establishing strategic guidelines to set frameworks for action and institutionalize how to approach climate adaptation in spatial planning (Boverket 2009; 2010; Nilsson et al. 2012). Surveys have shown that 90 percent of the municipalities, in their own rankings, approach climate adaptation in spatial planning and that 25 percent claim to do so "to a high degree" (SKL 2009). Further, surveys indicate that almost 40 percent of the municipalities have established principles or guidelines to support the mainstreaming of climate adaptation in spatial planning (SKL 2011), clearly suggesting a strengthened role for climate adaptation. Similar trends are noted in Denmark (Lund et al. 2012). Yet we know little of what this high degree stands for and what the process of enacting strategic guidelines look like in spatial planning practice. Recent international studies have suggested that municipalities have in fact proposed measures like guidelines and stricter codes for planning and building in an attempt to accommodate risks while still progressing ongoing land-use in 
risk-prone coastal zones (Moser et al. 2012, Wilby and Keenan 2012; Lund et al. 2012). In practice, this means that planning and building largely proceeds in risky areas despite knowledge of existing vulnerabilities, which may create path-dependent maladaptation (Barnett and O'Neill 2010). The identified trends clearly raise questions of how strategic guidelines are enacted and their effectiveness to support change.

To enhance knowledge of how the practical implementation of climate adaptation in spatial planning proceeds when standardized regulation and directives are formally in place, we take the positions of spatial planners as "frontline practitioners" supporting, implementing and maintaining reform in their every-day activities (Clifford 2012; Healey 2009; Newman 2008; Barrett 2004; Schofield 2004) as our starting-point. We hereby recognize the dependence on internal motivations for enacting change (O'Brien and Wolf 2010; Anguelovski and Carmin 2011). The aim of this paper is to analyze how frontline planners approach climate change adaptation in an urban context, emphasizing the process of settling and enacting strategic guidelines in spatial planning. Since a general trend in climate adaptation scholarship is that studies of planning for adaptation are more common than studies of actual implementation (Tompkins et al 2010; Preston et al 2011) this paper, by its emphasis on the implementation stage, directly contributes to the research field. Planners from ten Swedish municipalities who in national surveys claim to approach climate adaptation to a high degree in spatial planning are interviewed, allowing us to target the following research questions:

- How do planners approach climate adaptation in their working practice and what is the role of strategic guidelines?

- How do planners perceive the process of settling guidelines?

- How do planners perceive the process of enacting guidelines?

- What does this mean for the role and effectiveness of strategic guidelines to support climate adaptation in spatial planning?

After this first introductory section follows section two, presenting the Swedish policy context for climate adaptation in spatial planning. The third section gives the state of the art, positioning spatial planning in the adaptation process and planners as frontline practitioners and illustrating previous research initiatives in this field. Our qualitative methodological approach is described in section four. In section five, we present empirical results in two subsections, the first dealing with how climate change is approached by settling strategic guidelines whereas the second zooms in on the processes of enacting guidelines. In a final sixth section we highlight our key conclusions and discuss the role and effectiveness of strategic guidelines to support change.

\section{Climate adaptation in the Swedish context}

Climate adaptation has increasingly been recognised as a legitimate policy issue in Sweden. When the Committee on Climate and Vulnerability launched its final report in 2007, emphasis was put on the need for strategic planning and sector-wise mainstreaming of climate adaptation measures (SOU 2007:60). Although many risks were introduced, much practical 
work has come to centre on risks of flooding, erosion and sea-level rise (Lidskog et al. 2010). On a national level, the Swedish approach to climate adaptation has been characterized by a combination of network coordinative initiatives and knowledge generation, rather than any coherent and regulatory national strategy (Uggla 2009; Keskitalo et al. 2012; Glaas and Juhola 2013). In general adaptation is expected to take place at the local level where the 290 municipalities have extensive responsibilities for spatial planning and building, drainage and water supply, emergency planning and rescue services. Spatial planning has been identified as a key instrument for preventive climate adaptation (Prop 2008/09:162). In 2008, the former Swedish Planning and Building Act (PBL 1987:10) was complemented with statements that considerations of risks of flooding and erosion must be made in planning. In the new Act (2010:900) it is further clarified that municipalities have the responsibility to plan for new settlements with respect to climate change. This means that main locus of responsibility lies with municipalities who can be held liable for bad decisions up to ten years. (SOU 2007:60). In the last five years, a strengthened role has also been outlined for the County Administrative Boards to coordinate climate adaptation within the region. It has been suggested that regional delegations are established to support local efforts, provide, interpret and communicate knowledge as well as coordinate, press for action and assess ongoing work (Prop. 2008/09:162, SOU 2007:60). In the context of spatial planning, however, the local autonomy remains strong in Sweden.

The decentralised approach to spatial planning goes back to 1987 with municipalities holding the local monopoly of planning, where regional and national authorities can only intervene when national regulations are at risk of being violated (PBL 1987:10). At this point in time, the role of politicians was strengthened and the professional autonomy of planners was modified. Today planners use their professional competence to prepare needed decisionsupport and to fulfil visions that are politically settled (Uggla and Storbjörk 2012). Although the building constructors have to perform under existing plans and regulations, many municipalities are in practice dependent on private investments to ensure new settlements. The trend towards plan-making on demand, suggests a transformation where planning risk being less regulating with respect to private actors and more growth-oriented (Madureira 2013). In Sweden local spatial planning is structured around municipal comprehensive plans (MCP) and local development plans (LDP). The former specify goals for long-term land-use, prioritize and balance goals and clarify how national interests and environmental qualities are considered. The latter are concrete, detailed and project-oriented planning documents that regulate the development of new houses, roads, industries or other facilities in a certain area within the municipality. Since the MCP is not legally binding, the LDP is particularly influential for guiding change (Boverket 2010, p 28f).

The National Housing Agency have acknowledged that the PBA is efficient for climate proofing when it comes to adapting new settlements but ineffective when it comes to existing settlements (Boverket 2009; 2010). Although national surveys have shown that 90 percent of the municipalities approach climate adaptation in spatial planning (SKL 2009) we know less of what this means in practice. With the heavily decentralised Swedish planning system, where municipalities hold the local monopoly of planning and where the regional 
administrative level in Sweden is considered rather weak (Hilding-Rydevik et al. 2011; Storbjörk and Isaksson 2014), the actual performance of the Act is an open question.

\section{Planners approaching climate change: state of the art}

Research on climate adaptation mainstreaming emphasize that we need to analyze approaches, barriers and practices of adaptation found in different phases of the adaptation process (Moser and Ekstrom 2010; Juhola 2010; Mees et al. 2012; Dannevig et al. 2012). Such phases often refer back to policy literature and although they are named somewhat differently tend to stretch between problem definition, agenda setting, policy formation, deciding upon approaches, goals and measures, implementation and evaluation (Lundqvist 1987; Dovers 2005). Such phases can be clearly separated only at an analytical level. In practice, they are often intertwined and mutually shaped. With different regulatory mechanisms in place for Swedish spatial planning and evidence suggesting that municipalities are progressing in their work of approaching adaptation we would define the current process as being in between a phase of deciding upon approaches, goals and measures and a phase of implementation. There are high expectations on spatial planning being proactive in approaching climate adaptation rather than being reactive as documented by studies on early adaptation initiatives. While reactive adaptation refers to responding to observed or experienced impacts, proactive adaptation aims to reduce or avoid exposure to future risks (Smit et al. 2009). In planning theory, Albrechts has proposed a further distinction between proactive responses where changed mindsets and transformative practices allows "designing the future and making it happen" and, preactive responses, defined as "preparing for the future" (Albrechts 2010) while not necessarily enacting the same. This distinction between proactive and preactive provides a more nuanced way of characterizing responses to challenges. Whereas proactive in Albrechts definition suggests that implementation is occurring, preactive rather signals that although work is initiated, implementation is not yet taking place.

In this paper we understand the implementation of policy interventions as a process of negotiated order where the interactions between involved key actors lead to a dynamic mediation, negotiation and modification of intentions (Barrett 2004). Implementation involves interaction among actors with potentially diverging beliefs, perspectives, objectives, problem definitions, positions and strategies whose "comprehension, capability and willingness" of responding to the intervention is critical (Lipsky 1980; Lundqvist 1987; Jenkins-Smith and Sabatier 1994; Barrett 2004; Schofield 2004). This point to the importance of learning about the positions and perspectives of frontline practitioners in implementation (Clifford 2012; Healey 2009; Newman 2008; Barrett 2004; Schofield 2004). That responding to climate change is dependent on key actors initiating, mainstreaming and sustaining momentum has been highlighted in the adaptation literature (Bulkeley et al. 2009; Burch 2010; Moser and Ekstrom 2010; Tompkins et al. 2010; Garrelts and Lange 2011; Measham et al. 2011; Storbjörk and Hedrén 2011; Anguelovski and Carmin 2011; Runhaar et al. 2012). Consequently our analysis document the views of planners charged with practically fulfilling intentions of the Swedish PBA where climate change considerations are to be managed in 
planning. Although a zooming in on frontline practitioners is clearly motivated, we recognize that implementation depends upon a number of determinants such as general policy context, path dependency, timing, political support and local cultural practices.

Previous studies on the climate adaptation of spatial planning have reviewed the role of spatial planning by outlining capacities like coordinating, balancing and integrating knowledge claims, political intentions and competing interests in planning in a sense that is sensitive to local particularities while also incorporating different temporalities (Hurlimann and March 2012; Wilson and Piper 2009). Studies have also shown a gap between the perceived urgency of proactive adaptation in climate science and policy research and the perceptions of and approach to climate adaptation by urban planners (Runhaar et al. 2012; Dannevig et al. 2012). For the Dutch water sector, external barriers for how planners approach adaptation, like lack of political support, regulative demands and funding, uncertainties in knowledge and institutional fragmentation have been documented (Runhaar et al. 2012). These conclusions resonate well with findings from the substantial literature on barriers to adaptation. From a Swedish case-study internal challenges are identified arising from weak interplay between municipal comprehensive planning and local development plans (Storbjörk and Hjerpe 2013). Further, while some examples can be found of structural and regulatory measures being mainstreamed into regular planning processes as in the case of Stavanger where increased minimum building distance from the sea level has been decided upon (Dannevig et al. 2012: 606), studies have also suggested that mainstreaming is a dynamic process where norms are sometimes questioned and the extent of mainstreaming is constantly reconsidered in practice (Uittenbroek et al. 2012). Studies have documented how municipalities despite having proposed measures like strategic guidelines and stricter codes for planning and building in an attempt to "accommodate risks" in coastal areas, as opposed to managed retreat or strict defense options (Few et al. 2007; Vasey Ellis 2009; Alexander et al. 2011), in practical planning still progress with previous coastal occupancy (Moser et al. 2012, Wilby and Keenan 2012; Lund et al. 2012). This trend towards waterfront development, evident in Sweden and in many countries worldwide the latest decades, can be linked to redistribution and concentration of population to larger cities leading to increased inter-urban competition with strong political and economic incentives. Urban development of deindustrialized waterfront land and so-called "problem spaces" are being transformed in order to attract capital and well-off citizens. Many times this development, based on new kind of partnerships between private and public actors, result in new residential and commercial areas and gentrification (Desfor and Laidley 2011; Cowen and Bunce 2006).

To summarize, while there are studies documenting external or internal challenges to implementing climate adaptation in spatial planning, there is a need to further analyze processes of settling and enacting strategic guidelines. Based on insights from previous studies we explore how spatial planners as frontline practitioners approach adaptation in spatial planning practices. In the analysis, different layers and forms of negotiating climate concerns are highlighted. We also use the analytical distinctions of reactive, preactive and proactive approaches to climate adaptation. 


\section{Methodological considerations}

We have chosen to base our study on a selection of potentially proactive municipalities, identified from the Swedish SKL-survey from late 2009. Based on the results from the survey, SKL kindly sent out a question to the 200 responding municipalities (out of a total of 290) whether their names could be made public for follow-up studies. Of the 113 municipalities that gave their approval, 36 claimed to be working with climate adaptation to a high degree in their MCP:s, 30 in LDP:s and 30 in guidelines for planning/building. When comparing the lists, ten municipalities were identified as stating that they to a high degree approach climate adaptation in all three aspects. These municipalities were selected to be part of our study. Their different characteristics in terms of land area size, geographical location and degree of exposure to climate change risks are described in table 1.

Table 1: Municipality characteristics

\begin{tabular}{|l|l|l|l|l|}
\hline $\begin{array}{l}\text { Municipality } \\
\text { fictive name) }\end{array}$ & Land area & $\begin{array}{l}\text { Population } \\
\text { size }\end{array}$ & Geographical location & $\begin{array}{l}\text { Degree of exposure to } \\
\text { climate change risks (own } \\
\text { assessment) }\end{array}$ \\
\hline Westby & $475 \mathrm{~km}^{2}$ & 37500 & Mid West inland & Medium/High \\
\hline Smallby & $19 \mathrm{~km}^{2}$ & 16300 & South West coast & High \\
\hline Eastby & $1127 \mathrm{~km}^{2}$ & 13800 & South East inland & Medium \\
\hline Northby & $1065 \mathrm{~km}^{2}$ & 24700 & North East coast & Medium \\
\hline Deltaby & $1165 \mathrm{~km}^{2}$ & 84700 & Mid West inland & High \\
\hline Soundby & $56 \mathrm{~km}^{2}$ & 21000 & South West coast & High \\
\hline Urbanby & $335 \mathrm{~km}^{2}$ & 294000 & South West coast & High \\
\hline Vänerby & $602 \mathrm{~km}^{2}$ & 24000 & Mid West inland & High \\
\hline Rapidsby & $394 \mathrm{~km}^{2}$ & 4400 & Mid West inland & Medium \\
\hline Poleby & $102 \mathrm{~km}^{2}$ & 42600 & Mid East coast & Medium \\
\hline
\end{tabular}

When comparing municipality characteristics, it is clear that our diverse municipalities allow us to get a comparatively wide empirical material and study positions of spatial planners operating under different conditions. Interviews were done in late 2010 with a total of 15 planners, based on the organization of spatial planning within each municipality. Informants were selected after mapping who was knowledgeable and practically involved in working with the climate adaptation of spatial planning at both the strategic level, with the MCP:s and in concrete local development planning. In five municipalities the unit for spatial planning dealt with both MCP:s and LDP:s, meaning that only one representative was interviewed. In the other five municipalities, two representatives were interviewed as the responsibility for comprehensive and development plans was split between different units. The interviews followed an interview guide where questions of initiation and role of climate adaptation in spatial planning, concrete approaches and strategies for climate adaptation and dilemmas and challenges for implementation were discussed. Since the Swedish PBA specifically relates to the risk of flooding, erosion and sea-level rise, our interviews were designed to focus on these particular risks in spatial planning. The interviews lasted between $1-1 \frac{1}{2} \mathrm{~h}$ each and each interview was recorded and transcribed. 
Interview analysis means "reflecting upon the patterned character of participants' portrayals of action" (Silverman 2011, p 448). Our qualitative analysis of transcripts has been stepwise, combining meaning concentration, where the specific contents of each interview is explored, with meaning categorisation, highlighting reoccurring analytical themes with a particular bearing on approaches taken to climate adaptation in spatial planning as well as incentives and positions of spatial planners for more thorough analysis. This means that we present both individual viewpoints and more general patterns.

\section{Positions of frontline planners in climate adaptation}

Here we explore the positions of frontline spatial planners to support and maintain reform in their every-day activities. We illustrate approaches taken to climate change adaptation, zooming in on the process of settling strategic guidelines and enacting the same.

\subsection{Accommodating climate risks and settling strategic guidelines}

Whereas sea-level rise and erosion are relevant climate risks only in some of our ten municipalities, flooding due to increased precipitation, snow-melt and extreme weather events is relevant in all. In an urban context, these risks are often aggravated by the amount of paved ground negatively influencing infiltration. The main strategy to integrate considerations to climate risks is a combined approach of developing hard protective measures to secure urban settlements and facilitating a step-wise accommodation of land-use intended to adjust to climate risks. No municipality is considering a strategy of planned retreat from risky locations. At the time of the interviews Eastby, Rapidsby, Smallby and Vänerby, were in the process of strategically considering climate change and here interviewees made clear that climate change was to be approached in upcoming revisions of the MCP. So far however they had solely dealt with consequences of current climate variability and we rather witness preparations for approaching climate adaptation than high degree proactive planning. In three of these municipalities, Vänerby, Eastby and Rapidsby, planners were hesitant about the potential to formulate valid strategic guidelines and found it to be more realistic to deal with climate risks on a case-by-case basis. They expressed a lack of resources or competence to develop guidelines (Interviews 4, 12-14). This signals a strategy of accommodation on an incremental case-by-case basis rather than following a coordinated and coherent strategy (Nilsson 2007; Hrelja 2011).

Out of the remaining six municipalities, we identify clearer positions in how to strategically accommodate climate change in spatial planning. Poleby and Deltaby work with more innovative forms of adjusted waterfront housing, like piled or floating houses (Interviews 6 and 15). Urbanby distinguishes itself by envisioning innovative future and multi-functional measures for coastal protection in the form of land-fill artificial islands, creating new areas for planning and expanding urban coastline areas (Interviews 10-11). Similar innovative adaptation measures are used in cities like Rotterdam to "profiling the city" for water management and maintaining its attractiveness by multi-purpose dams, dykes and water plazas (Runhaar et al. 2012). Besides these examples the main instrument in spatial planning evolve around either standardized routines for detailed development planning where climate 
change is made part of regular checklists as in Northby, or specific strategic guidelines to guide and set frameworks for concrete development planning as in the five municipalities of Poleby, Deltaby, Westby, Urbanby and Soundby.

The strategic guidelines for areas at risk of flooding and/or sea-level rise in the five municipalities come in the form of specifying both what return period, i.e. the probability of flood occurrence which is an average value expressing the frequency at which a flood of a certain size is expected (SOU 2007, p. 60), are the basis for the guidelines and what minimum building distance for waterfront housing is allowed (as was also shown by Dannevig et al. 2012 for Stavanger). The municipalities also make distinctions between what kinds of buildings are allowed in areas with lower and higher probability of flooding. It is stated in Deltaby that only in areas with low probabilities, buildings of higher social and economic values are still considered but then further studies needs to be made about the risks and protective measures needed to secure areas. The interviews also show that deciding upon what return periods should form the basis of recommendations is locally determined and varies heavily among municipalities, suggesting that deciding upon what to adapt to is still far from evident. For example, Deltaby have, in their flood program for 2010, settled for a flood frequency of a 200 year return period with added margins for climate change (Deltaby 2010, p 91). They have not, however, chosen to include a worst case scenario, which other municipalities like Westby have done (Interview 2), although this was suggested by the Swedish Committee on Climate and Vulnerability. A worst case scenario would imply floods occurring simultaneously, which locally seen as "too unlikely" (Interviews 6-7). Difficulties in using national recommendations were mentioned also in other municipalities:

"If we were to consider results from the Swedish Committee on climate and vulnerability then we would end up very far off. We have to find a level that works." (Interview 12)

In this process of deciding what to adapt to, municipalities on the one hand consider input from existing scenarios, assessments and recommendations from national or regional authorities while, on the other hand, it is local officials who determine what is a reasonable approach in their specific municipality, following principles of local autonomy.

Determining appropriate levels is described as tricky also with reference to scientific uncertainties, confirming conclusions in previous studies (Pielke 1999; Storbjörk 2007; Uggla 2009; Juhola 2010; Moser and Ekstrom 2010; Klein and Juhola 2014). Guidelines are built on scenarios of the future which are seen as too uncertain to be accepted outright and dictate current affairs, as suggested by the following quote from Poleby:

"We cannot decide on 5 meters /as opposed to 3/ because it may - and this we don't know with enough certainty - in a 100 years be a reasonable limit. The acceptance is not that strong and the economic loss would be too big" (Interview 15. Similar 5-7, 12).

Also with respect to uncertainties, settling strategic guidelines thus involves negotiating reasonable limits. Besides illustrating the role of uncertainty and temporality, the quote also 
illustrates different values at stake and the pragmatic negotiation between concerns of safety and economy. The planners further see any guideline for climate change as temporary as they have already witnessed them being gradually sharpened and in constant need of updating following best available knowledge:

"Even if our work on climate change is recent it has already become obsolete. We have to stay updated. It is difficult since planning is long-term and knowledge quickly changes" (Interview 2. Similar 8, 10-11,15)

To conclude the empirical data points to settling strategic guidelines being characterized by negotiating reasonable approaches in light of uncertainties and changing knowledge. Still, the process of formulating guidelines involves an expectation that they will set frameworks for action and institutionalize how to approach climate adaptation.

\subsection{Enacting strategic guidelines}

With strategic guidelines in place in five out of ten municipalities follows a need to enact the guidelines in daily planning practices. This brings new challenges. In the perspective of planners it is clear that the guidelines that have been seen as such an important part of institutionalizing adaptation in spatial planning are not generally applicable. This has become particularly clear for the four municipalities that since settling guidelines have conducted concrete local development planning in lowland waterfront areas. As one interviewee in Urbanby states:

"We have our guidelines but we have also discussed if we can use them straight off. It is clear that off course we can't" (Interview 11. Similar 7-10)

Planners that have decided upon guidelines clarify that the problems of enacting guidelines relate either to accomplishing accessibility and aesthetics in city-making practices or to maintaining a much desired flexibility in planning, allowing planners to fulfil their professional mandates of coordination and compromise.

First, we see in our interviews that strategic guidelines become problematic in concrete development planning where the goal becomes one of finding workable solutions and practical ways of approaching risks. Here, the enactment of strategic guidelines in the ongoing process of urban development involves practical problems of both accessibility and aesthetics:

"There are situations where you have already built on two spots with an available space in between and if you would apply stricter recommendations there it would look strange, we would have problems with accessibility and you would still have to protect the other two spots." (Interview 11. Similar 7-10)

This is a recurrent discussion in many interviews since current city-making practices are increasingly targeted at urban densification to avoid sprawl and make possible sustainable urban development structures. Managing contrasting goals in planning is clearly difficult for planners as it comes down to how the new waterfront limits meets older city structures: 
"We have said that all new settlements should be located at +3 meter but many existing areas are located much lower. We have old buildings from the $18^{\text {th }}$ Century and we want the new settlements to meet the old at similar levels while at the same time meeting the new demands. We are not sure how to do this" (Interview 10. Similar 8-11).

The quotes clearly suggest that enacting guidelines can become very problematic.

Second, we see some key trends in the reasoning of planners that enacting guidelines is a messy process of negotiating order since maintaining flexibility in planning is the overarching principle. Despite their intention of setting at least temporary limits based on best available knowledge (Interview 2, 8, 15) guidelines are by necessity seen as negotiable. Such negotiability is part of the coordination and balancing of claims in planning:

"Our position is that we need to be able to build our city in a way that still allows us to consider the risks of flooding. We need to be able to combine considerations" (Interview 7. Similar 8-9)

In these interpretations spatial planning is all about finding a compromise, allowing planners to fulfil their professional mandates of coordinating, balancing and integrating knowledge claims, political intentions and competing interests (Hurlimann and March 2012; Wilson and Piper 2009). Planners are generally keen on preserving such flexibility in the application of guidelines, suggesting explicitly that the goal is not to "conserve" the use of guidelines but rather allow opportunities for assessing what needs to be done in different situations. We thus identify a double-edged position in relation to strategic guidelines. On the one hand they are seen as an important element of outlining a role for climate adaptation but on the other hand they are by no means intended to be absolute or strict in setting frameworks for practical action. In practice, it is fair to say that even with strategic guidelines in place; climate adaptation in spatial planning is made on a case-by-case basis and by negotiating order. In all but one of the ten municipalities, the exception being one of the richest municipalities in Sweden with extensive waterfront settlements where the need to attract new citizens is next to nil, increased waterfront planning is encouraged and embraced by local goals and ambitions. This trend towards waterfront residential and commercial areas in urban planning is partly based on strategic consideration on how to attract capital to the municipality (Desfor and Laidley 2011; Cowen and Bunce 2006). Many times the planners feel politically pressed to ensure this type of projects and in local development planning bound to negotiate and comply with demands from private housing companies. In spite of the climate risks involved in such undertakings, being able to facilitate waterfront settlements is an overarching concern, which spurs the negotiability of guidelines, as interviews recurrently show:

"To build flood-proof is not to build in lowland waterfront areas but these are the areas the market wants and where we have a lot of plans today. /.../ We want to be able to stand next to the water and say "we want to build here" rather than withdrawing to the mountains" (Interview 7. Similar 1, 6-8, 10-12) 
Here our interviews confirm conclusions from previous studies that dealing with flood risks can end up being at odds with local planning strategies aimed at developing attractive waterfront areas (Næss et al 2005; Bulkeley 2006; Storbjörk 2007; Uggla 2009; RomeroLankao 2012; Wilby and Keenan 2012). Nine out of ten municipalities state that an important goal is to increase rather than restrict waterfront settlements. Some planners see it as their role to make sure that waterfront planning meets the local strategic guidelines whereas others, particularly those facing population decline and weak economies, state that they want to be attractive for private developers rather than putting pressures on them to fund expensive protective measures. Although some the municipalities are equipped with hilly and much less risky shorelines (Interviews 1, 2, 5, 15) planners often discuss that in retrospect many problematic waterfront areas have been built and are still increasingly planned for (Interview 6-8, 10-12).

Justifications for pursuing the path of continued waterfront development instead of applying strategies of retreat or precautionary principles are discussed. One key argument supporting continued expansion concerns existing settlement patterns. Several municipalities claim that current settlements patterns, however unsustainable from the perspective of climate risks, justify continued waterfront development:

"We already have much existing settlements in waterfront areas so there is no point in saying no to further waterfront planning. We cannot move the whole city" (Interview 8. Similar 7-11)

This strongly suggests path-dependencies involved in urban development, where climate change is not really allowed to fundamentally challenge ongoing urban development patterns. That tendencies of path-dependency have limited climate adaptation practice has been identified in other studies on climate adaptation (Garrelts and Lange 2011) but the results here suggest that this takes place also in light of strategic guidelines. Since existing urban areas still needs to be secured by various protective measures, future protective measures will step in and provide the needed adaptive measures suggesting that waterfront spatial planning might just as well continue. In this sense climate adaptation is not really an issue for current spatial planning but rather becomes a future large-scale urban security concern where concrete decisions and investments are postponed and delegated to other agents. Another key argument supporting continued urban expansion in waterfront areas can theoretically be discussed in terms of "the tyranny of small decisions" meaning that decisions are seen as singular events without raising questions on what direction the sum of individual decision takes urban planning (Hrelja 2011). The argument is exemplified by the following quote:

"You need to think about what you can accomplish in a singular development plan. We shouldn't worsen things but taking precautions here won't improve matters in general." (Interview 7. Similar 8-11)

Again enacting strategic guidelines is turned into a negotiation where the usefulness of singular applications is questioned. As with the former argument, instead of taking measures in spatial planning, climate adaptation is transformed into a future concern where spatial planning is not necessarily the right addressee. 
The quotes presented suggest that settling strategic guidelines is but the start of dealing with climate change adaptation in spatial planning. Enacting the same guidelines is a different matter and although guidelines have been settled, decisions will still be made case-by-case to allow maximum flexibility. This however means that enacting the formulated guidelines is a matter of negotiation. Interviewees see this as a part of the professional mandate of planners, discussing that planning is essentially about negotiating, mediating and balancing various claims, concerns and interests and here climate adaptation does not differ from other concerns. We let one of the planners exemplify this point:

"If we would take all matters into consideration in planning we wouldn't be able to build anything. Planning is all about finding compromises" (Interview 3.

Similar 1-2, 4-15)

Although compromising is a natural element of spatial planning, this brings implications for to what extent climate adaptation risks are acknowledged in practical planning and what role spatial planning can play. This leads us to our conclusions.

\section{Conclusions}

In outlining our conclusions for how frontline planners approach climate change adaptation in spatial planning, it seems reasonable to speak in terms of these municipalities at best taking a preactive approach, i.e. preparing to take measures. It is not a matter of wait and see or simply reacting to experiences, nor is it fair to characterize it as proactive adaptation in the sense of enacting change. Rather we witness increased preparations for action in the municipalities. At the same time the enactment that does take place in spatial planning is characterized by maintaining flexibility where concrete decisions and investments are postponed and delegated to other agents. It is clear that the aim is not precautionary retreat from risky areas but rather a combined approach of defence by solid protective measures and accommodation by stricter building codes in an attempt to create maximum short-term flexibility by allowing municipalities to accommodate risks while progressing and also increasing ongoing coastal occupancy (Moser et al. 2012, Lund et al. 2012; Amundsen et al. 2010). From the interviews it is clear that climate change is not allowed to substantially challenge ongoing urban development patterns in lowland and risky waterfront areas. Given the case-study selection in our study, where we target municipalities of different size, geographical location and risk profiles that state they are approaching adaptation to a comparatively high degree, it is reasonable to assume that the trends, obstacles and quandaries expressed here are likely to be relevant, and perhaps even more so, in other Swedish municipalities.

In the paper we also establish the difference between settling and enacting strategic guidelines. The necessity of making this distinction comes from comparing policyexpectations and empirical analyses where the latter show that settling guidelines represent but the start of a process and not something that guarantees enactment. In fact, our analysis allows us to emphasize the different layers and forms of negotiating order involved in both settling and enacting strategic guidelines. In settling guidelines, negotiation means deciding 
upon reasonable limits and safety-margins for planning based on assessing relevant knowledge, uncertainties and temporalities. In enacting guidelines, negotiation means muddling through the case-by-case identification of practically workable solutions where the new waterfront limits meets visual and aesthetic concerns and demands for accessibility. Negotiation also means questioning the usefulness of singular applications of guidelines where the overarching concern of maintaining flexibility in planning by combining different strategic considerations is at the heart of the professional mandate and focus of planners. Also, since existing urban areas needs to be protected, it is assumed that waterfront spatial planning might just as well continue meanwhile. Climate adaptation is thus transformed into a future concern where spatial planning is not necessarily the right addressee. Negotiating the order of climate adaptation does not stop with the settling of strategic guidelines but is an immanent part of the process of adapting to climate change in spatial planning. Also, the guidelines in themselves are not necessarily proactive in terms of "designing the future and making it happen" since their effectiveness all fall back to how they are actually implemented in daily planning. Here planners have other chief concerns about maintaining flexibility rather than having climate change dictate urban development. In the perspective of our frontline planners, planning is essentially about compromising and managing processes of negotiating order by bearing different perspectives, interests and goals in mind and here climate change is one concern of many to be considered, balanced and negotiated. The strong focus on the potential of waterfront planning to attract capital and private building companies, itself being a wider trend in urban development, is one factor that enhances negotiation and pragmatism.

Our empirical observations also allow us to problematize the role and effectiveness of spatial planning and strategic guidelines to support change. With the strong local monopoly of planning in our heavily decentralized Swedish planning system, approaching climate adaptation in spatial planning clearly means different things in the municipalities. However, all ten municipalities have clear problems with following and fulfilling the intentions of the Planning and Building Act. Climate change is dealt with but in the process is subject to negotiations and pragmatism. Even though the whole idea with strategic local guidelines is to strategically clarify and institutionalize statements for climate adaptation, enacting guidelines in planning practice still necessitates a case-by-case incremental approach. On the one hand, it can be argued that this use of guidelines is perfectly in line with what a guideline is, since it not meant to be a strict rule. On the other hand, one could also argue that this enactment becomes problematic since a lot of faith is put into guidelines serving as instruments to secure a practical role for climate change considerations in spatial planning and here the guidelines simply do not seem to deliver. Planning practice simply does not allow for that kind of standardization. Rather it is up to the specific decision-making practices surrounding singular local development plans at hand to settle and negotiate order in terms of appropriate measures and ways to account for climate change. This does not mean that strategic guidelines do not have a value in pursuing climate adaptation. Strategically reflecting upon where to go and the role of climate risks in a particular location is a critical part of processing climate adaptation. Subsequently this study suggest that we do need to nuance and revise our understanding of what role strategic guidelines can realistically play in the practice of adapting to climate change in spatial planning, with the current Swedish planning system. 


\section{Acknowledgements}

To the interviewed planners for generously sharing their views, perspectives and experiences of working with climate adaptation in spatial planning. To the Swedish Research Council for Environment, Agricultural Sciences and Spatial Planning (FORMAS) for funding the research project "Planning for climate adaptation: adaptive capacity and conditions for change" (Dnr.214-2006-146) during which the interviews were conducted and transcribed. The analysis and writing of the paper was made possible with funding from the Department of Water and Environmental Studies at Linköping University (paper grant) and the FORMAS research project CLIPP "Climate change policy integration in local policy and planning" (Dnr.242-2011-1599).

\section{References}

Adger NW, Agrawala S, Mirza MMQ, Conde C, O’Brien K, Pulhin J, Pulwarty R, Smit B, Takahashi K (2007) Assessment of adaptation practices, options, constraints and capacity. In Parry M L, Canziani OF, Palutikof JP, van der Linden PJ, Hanson CE (Eds) Climate Change 2007: Impacts, Adaptation and Vulnerability. Cambridge University Press, Cambridge, UK, pp 717-743.

Adger NW, Barnett J (2009) Four reasons for concern about adaptation to climate change. Environment and Planning A 41:2800-2805. DOI: 10.1068/a42244

Albrechts L (2010) More of the same is not enough! How could strategic spatial planning be instrumental in dealing with the challenges ahead. Environment and Planning B 37:11151127. DOI: $10.1068 / \mathrm{b} 36068$

Alexander KS, Ryan A, Measham TG (2012) Managed retreat of coastal communities. Journal of Environmental Planning and Management 55:409-433. DOI: $10.1080 / 09640568.2011 .604193$

Amundsen H, Berglund F, Westskog H (2010) Overcoming barriers to climate change adaptation - a question of multilevel governance? Environment and Planning C 28:276-289. DOI: $10.1068 / \mathrm{c} 0941$

Anguelovsky I, Carmin J (2011) Something borrowed, everything new: innovation and institutionalization in urban climate governance. Current Opinion in Environmental Sustainability 3:169-175. DOI: 10.1016/j.cosust.2010.12.017

Barnett J, O'Neill S (2010) Maladaptation. Global Environmental Change 20:211-213. DOI: 10.1016/j.gloenvcha.2009.11.004

Barrett SM (2004) Implementation studies: Time for a revival? Public Administration 82:249262. DOI: $10.1111 / \mathrm{j} .0033-3298.2004 .00393 . \mathrm{x}$ 
Biesbroek GR, Swart RJ, van der Knaap WGM (2009) The mitigation-adaptation dichotomy and the role of spatial planning. Habitat International: 230-237. DOI:

10.1016/j.habitatint.2008.10.001

Blanco H, Alberti M (2009) Hot, congested, crowded and diverse: Emerging research agendas in planning. Progress in Planning 71:153-205. DOI: 10.1016/j.progress.2009.03.001

Boverket (2009) Bygg för morgondagens klimat. [Build for the climate of tomorrow]. Boverket, Karlskrona, Sweden.

Boverket (2010) Klimatanpassning i planering och byggande [Climate adaptation in planning and building]. Boverket, Karlskrona, Sweden.

Bulkeley H, Schroeder H, Janda K, Zhao J, Armstrong A, Chu SY, Ghosh S (2009) Cities and climate change: the role of institutions, governance and urban planning. Report prepared for the World Bank Symposion on Climate Change.

Burch S (2010) Transforming barriers into enablers of action on climate change: Insights from three municipal case studies in British Columbia, Canada. Global Environmental Change 20:287-297. DOI: $10.1016 /$ j.gloenvcha.2009.11.009

Campbell H (2006) Is the issue of Climate Change too Big for Spatial Planning? Planning Theory \& Practice: 201-230. DOI: 10.1080/14649350600681875

Clifford BP (2012) Reform the Frontline: Reflections on Implementing Spatial Planning in England. Planning Practice \& Research. DOI:10.1080/02697459.2012.725550.

Cowen D, Bunce S (2006) Competitive Cities and Secure Nations. International Journal of Urban and Regional Research 30:427-439. DOI: 10.1111/j.1468-2427.2006.00670.x

Dannevig H, Rauken T, Hovelsrud G (2012) Implementing adaptation to climate change at the local level. Local Environment 17:597-611. DOI: 10.1080/13549839.2012.678317

Davoudi S, Crawford J, Mehmood A (2009) Planning for Climate Change. Earthscan, London, UK.

Desfor G, Laidley J (2011) Fixity and Flow of Urban Waterfront Change. In: Desfor G, Laidley J, Stevens Q and Schubert D. (eds) Transforming Urban Waterfronts. Routledge, London, UK.

Dovers S (2005) Environment and Sustainability Policy. Creation, implementation and evaluation. The Federation Press, Sydney, Australia.

Dovers SR, Hezri R (2010) Institutions and policy processes. Wiley Interdisciplinary Reviews: Climate Change 1:212-231. DOI: 10.1002/wcc.29

Few R, Brown K, Tompkins E (2007) Climate Change and Coastal Management Decisions. Coastal Management 35:255-270. DOI: 10.1080/08920750601042328 
Garrelts H, Lange H (2011) Path Dependencies and Path Change in Complex Fields of Action: Climate Adaptation Policies in Germany in the Realm of Flood Risk Management. AMBIO 40:200-209. DOI: 10.1007/s13280-010-0131-3

Glaas E, Juhola S (2013) New Levels of Climate Adaptation Policy: Analyzing the Institutional Interplay in the Baltic Sea Region. Sustainability 5:256-275. DOI: $10.3390 /$ su5010256

Glaas E, Jonsson A, Hjerpe M, Andersson-Sköld Y (2010) Managing climate change vulnerabilities: formal institutions and knowledge use as determinants of adaptive capacity at the local level in Sweden. Local Environment 15:525-539. DOI: $10.1080 / 13549839.2010 .487525$

Healey P (2009) In Search of the "Strategic" in Spatial Strategy Making. Planning Theory \& Practice 10:439-457. DOI: 10.1080/14649350903417191

Hilding-Rydevik T, Håkansson M, Isaksson K ( 2011) The Swedish Discourse on Sustainable Regional Development: Consolidating the Post-Political Condition. International Planning Studies 16:169-187. DOI: 10.1080/13563475.2011.561062

Hrelja R (2011) The Tyranny of Small Decisions. Unsustainable Cities and Local Day-to-Day Transport Planning. Planning Theory \& Practice:511-524. DOI: 10.1080/14649357.2011.626312

Huitema D, Mees H, Vermeer K, Storbjörk S, Garrelts H, Grecksch K, Winges M, Rayner T (2012) Handling adaptation governance choices in Sweden, Germany, the UK and the Netherlands. Report W-12/07. IVM, Amsterdam, Netherlands.

Hurlimann AC, March AP (2012) The role of spatial planning in adapting to climate change. Wiley Interdisciplinary Reviews: Climate Change:477-488. DOI: 10.1002/wcc.183

Jenkins-Smith HC, Sabatier PA (1994) Evaluating the Advocacy Coalition Framework. Journal of Public Policy 14:175-203.

Juhola S (2010) Mainstreaming climate change adaptation. In: Keskitalo ECH (ed) Developing adaptation policy and practice in Europe. Springer, London, UK, pp 149-188.

Keskitalo ECH, Juhola S, Westerhoff L (2012) Climate change as governmentality. Journal of Environmental Planning and Management 55:435-452. DOI: 10.1080/09640568.2011.607994

Klein RJT, Juhola S (in press) A Framework for Nordic Actor-Oriented Climate Adaptation Research. Environmental Science and Policy. DOI: 10.1016/j.envsci.2014.01.011

Lidskog R, Soneryd Y, Uggla Y (2010) Transboundary Risk Governance. Earthscan, New York, US.

Lipsky M (1980) Street Level Bureaucracy. Russell Sage, New York, US. 
Lund DH, Sehested K, Hellesen T, Nelleman V (2012) Climate change adaptation in Denmark. Local Environment 17:613-628. DOI: 10.1080/13549839.2012.678318

Lundqvist L (1987) Implementation Steering. Studentlitteratur, Lund, Sweden.

Madureira, AM (2013) Physical Planning in Entrepreneurial Governance. European Planning studies DOI:10.1080/09654313.2013.843650.

Measham TG, Preston BL, Smith TF, Brooke C, Gorddard R, Withycombe G, Morrison C (2011) Adapting to climate change through local municipal planning. Mitigation and Adaptation Strategies for Global Change 16:889-909. DOI: 10.1007/s11027-011-9301-2

Mees H, Driessen P, Runhaar H (2012) Exploring the scope of public and private responsibilities for climate adaptation. Journal of Environmental Policy and Planning 14 (3): 305-330. DOI: 10.1080/1523908X.2012.707407

Moser SC, Williams SJ, Boesch DF (2012) Wicked Challenges at Land's End: Managing Coastal Vulnerability Under Climate Change. Annual Review of Environment and Resources 37:51-78. DOI: 10.1146/annurev-environ-021611-135158

Moser SC, Ekstrom JA (2010) A framework to diagnose barriers to climate change adaptation. Proceedings of the National Academy of Science 107:22026-22031. DOI: 10.1073/pnas.1007887107

Newman P (2008) Strategic Spatial Planning. European Planning Studies 16:1371-1383. DOI: $10.1080 / 09654310802420078$

Nilsson AE, Gerger Swartling Å, Eckerberg K (2012) Knowledge for local climate change adaptation in Sweden. Local Environment 17:751-767. DOI: 10.1080/13549839.2012.678316

Nilsson K (2007) Managing complex spatial planning processes. Planning Theory \& Practice 8:431-447. DOI: 10.1080/14649350701664473

Næss LO, Bang G, Eriksen S, Vevatne J (2005) Institutional adaptation to climate change. Global Environmental Change 15:125-138. DOI: 10.1016/j.gloenvcha.2004.10.003

O'Brien K, Wolf J (2010) A values-based approach to vulnerability and adaptation to climate change. Wiley Interdisciplinary reviews: Climate Change 1:232-242. DOI: 10.1002/wcc.30

PBL 1987:10, 2010:900 Plan- och Bygglagen. [Planning and Building Act]. SFS Regeringskansliet, Stockholm, Sweden.

Pielke RA Jr, Prins G, Rayner S, Sarewitz D (2007) Lifting the taboo on adaptation. Nature 445:597-598. DOI: $10.1038 / 445597$ a

Pielke RA Jr (1999) Who decides? Forecasts and responsibilities in the 1997 Red River flood. Applied Behavioural Science Review 7:83-101. 
Preston BL, Westaway RM, Yuen EJ (2011) Climate adaptation planning in practice. Mitigation and Adaptation Strategies for Global Change 16:407-438. DOI: 10.1007/s11027010-9270-X

Prop. 2008/09:162 En sammanhållen klimat- och energipolitik [A joint politics for climate and energy]. Regeringskansliet, Stockholm, Sweden.

Rayner T (2012) UK Adaptation Policy. In: Huitema D, Mees H, Vermeer K, Storbjörk S, Garrelts H, Grecksch K, Winges M, Rayner T (eds) Handling adaptation governance choices in Sweden, Germany, the UK and the Netherlands. Report W-12/07. IVM, Amsterdam, Netherlands, pp 31-52.

Romero-Lankao P (2012) Governing Carbon and Climate in the Cities. European Planning Studies 20:7-26. DOI: 10.1080/09654313.2011.638496

Runhaar H, Mees H, Wardekker A, van der Sluijs J, Driessen PPJ (2012) Adaptation to climate change-related risks in Dutch urban areas. Regional Environmental Change 4:750777. DOI: $10.1007 / \mathrm{s} 10113-012-0292-7$

Schofield J (2004) A model of learned implementation. Public Administration 82:67-78. DOI: $10.1111 / j .0033-3298.2004 .00395 . x$

Silverman D (2011) Interpreting Qualitative Data. Sage, London, UK.

SKL (2009) Läget i landet. En enkätundersökning om klimatanpassning i den fysiska planeringen [A survey on climate adaptation in spatial planning]. SKL, Stockholm, Sweden.

SKL (2011) Kommunernas arbete med klimatanpassning [Municipalities working with climate adaptation]. SKL, Stockholm, Sweden.

Smit B, Burton I, Klein RJT, Wandel J (2009) An Anatomy of Adaptation to Climate Change and Variability. In Schipper EL, Burton I (eds) The Earthscan Reader on Adaptation to Climate Change. Earthscan, London, UK, pp 63-88.

SOU 2007:60 Sverige inför klimatförändringarna - hot och möjligheter [Sweden Facing Climate Change - Threats and Opportunities]. Fritzells, Stockholm, Sweden.

Storbjörk S, Isaksson K (2014) "Learning is our Achilles heel". Conditions for long-term environmental policy integration in Swedish regional development programming. Journal of Environmental Planning and Management 57:1023-1042. DOI: $10.1080 / 09640568.2013 .779232$

Storbjörk S, Hjerpe M (2013) "Sometimes Climate Adaptation is Politically Correct": A Case Study of Planners and Politicians Negotiating Climate Adaptation in Waterfront Spatial Planning. European Planning Studies. DOI:10.1080/09654313.2013.830697

Storbjörk S, Hedrén J (2011) Institutional capacity-building for targeting sea level rise in the climate adaptation of Swedish coastal zone management. Lessons from Coastby. Ocean and Coastal Management 54:265-273. DOI: 10.1016/j.ocecoaman.2010.12.007 
Storbjörk S (2007) Governing Climate Adaptation in the Local Arena. Local Environment 12:457-469. DOI: $10.1080 / 13549830701656960$

Swart R, Biesbroek R, Binnerup S, Carter TR, Cowan C, Henrichs T, Loquen S, Mela H, Morecroft M, Reese M, Rey D (2009) Europe Adapts to Climate Change. PEER Report 1, Helsinki, Finland.

Tompkins EL, Adger WN, Boyd E, Nicholson-Cole S, Weatherhead K, Arnell A (2010) Observed adaptation to climate change. Global Environmental Change 20:627-635. DOI: 10.1016/j.gloenvcha.2010.05.001

Uggla Y, Storbjörk S (2012) Klimatrisker på planerarnas agenda: att hantera motstridiga krav och kunskapsosäkerhet [Climate risks on planners' agendas: handling opposing demands and uncertainties in knowledge]. Dansk Sociologi 23:73-95.

Uggla Y (2009) Framtiden är inte längre vad den varit [The future is not as it was]. In: Uggla Y, Elander I (eds) Global uppvärmning och lokal politik [Global warming and local politics]. Santérus Academic Press, Stockholm, Sweden, pp. 109-128.

Uittenbroek CJ, Janssen-Jansen LB, Runhaar HAC (2012) Mainstreaming climate adaptation in urban planning. Regional Environmental Change. DOI:10.1007/s10113-012-0348-8.

Urwin K, Jordan A (2008) Does public policy support or undermine climate change adaptation? Global Environmental Change 18:80-191. DOI: 10.1016/j.gloenvcha.2007.08.002

Vasey Ellis N (2009) Planning for Climate Change in Coastal Victoria. Urban Policy and Research 27:157-169. DOI: 10.1080/08111140902950487

Wilby RL, Keenan R (2012) Adapting to flood risk under climate change. Progress in Physical Geography 36:348-378. DOI: 10.1177/0309133312438908

Wilson E (2006) Adapting to Climate Change at the Local Level: The Spatial Planning Response. Local Environment: 609-625. DOI: 10.1080/13549830600853635

Wilson E, Piper J (2010) Spatial Planning and Climate Change. Routledge, London, UK. 